ISSN 2080-1653

\author{
JACEK SOŁTYS \\ Politechnika Gdańska, Polska \\ Gdansk University of Technology, Poland \\ SŁAWOMIR DOROCKI \\ Uniwersytet Pedagogiczny w Krakowie, Polska \\ Pedagogical University of Cracow, Poland
}

\title{
Rozmieszczenie ustug jako podstawa rozpoznawania ośrodków podregionalnych w Polsce i ich hierarchii
}

\section{Location of Services as the Basis for Recognising Sub-Regional Centres in Poland and their Hierarchy}

\begin{abstract}
Streszczenie: Ośrodki podregionalne definiowane są jako miasta, w których skoncentrowane są takie usługi, które w Polsce mogą występować w kilku miastach województwa, ale nie w każdym mieście powiatowym. Usługi zawsze miały tendencję do koncentracji, tworząc ośrodki różnych poziomów w hierarchicznej sieci osadniczej. Celem prezentowanych badań było: (1) określenie usług typowych dla poziomu podregionalnego; (2) rozpoznanie koncentracji tych usług, tworzonych przez nie ośrodków i ich rozmieszczenia oraz (3) ocena, w jakim stopniu występują prawidłowości hierarchicznego modelu lokalizacji usług na poziomie podregionalnym w Polsce. Takie usługi w Polsce, poza obszarami metropolitalnymi i miastami wojewódzkimi, były przedmiotem badań. Za usługi typowe, definiujące ośrodki podregionalne, uznano: sądy okręgowe, szpitale wielospecjalistyczne, wyższe uczelnie i kina multipleksowe. Zbadano metodą klasyfikacji zróżnicowanie ośrodków, a poprzez analizę kartograficzną - ich rozmieszczenie. Badania, będące kontynuacją badań z 2015 roku, uwzględniające aktualniejsze dane i szerszy zakres usług, wykazały 23 ośrodki podregionalne pełne i 47 niepełnych, w których zestawy usług tworzą różne kombinacje, z dwoma dominującymi. Jako prawidłowość stwierdzono dużą koncentrację usług. Rozmieszczenie ośrodków jest nierównomierne, prawdopodobnie z powodu zróżnicowania gęstości zaludnienia.
\end{abstract}

\begin{abstract}
Sub-regional centres are defined as towns, in which there are concentrated the types of services that in Poland may exist in several towns of the voivodeship, but not in every capital of poviat (county). The services have always had a tendency to concentrate, creating service centres of different levels in hierarchical settlement network. The objectives of the present research were: (1) definition of services typical of the sub-regional level; (2) recognition of the concentration of these services, the centres created by them and their distribution, and (3) verification to which extent the regularity relate to the concentration of services in hierarchical centres at the sub-regional level in Poland. Presented study includes only centres apart metropolitan areas and apart capital of voivodeships. Typical services defining sub-regional centres were: courts of second instance, multi-specialised hospitals, universities and multiplexes. The diversity of centres was analysed with the use of the classification method and their distribution - by cartographic analysis methods. The research was a continuation of research from 2015. Taking into account more recent data and a wider range of services, it identified 23 sub-regional complete centres and 46 incomplete ones, in which sets of services create different combinations, with two dominant ones. The regularity relating to the concentration of services was stated. The location of centres is uneven, probably due to the diversity of population density.
\end{abstract}

Słowa kluczowe: lokalizacja usług; ośrodki obsługi; ośrodki podregionalne; ośrodki subregionalne, sieć osadnicza; usługi podregionalne

Keywords: location of services; service centres; settlement network; sub-regional centres; sub-regional services 
Otrzymano: 7 stycznia 2018

Received: 7 January 2018

Zaakceptowano: 9 lipca 2018

Accepted: 9 July 2018

\section{Sugerowana cytacja / Suggested citation:}

Sołtys, J., Dorocki, S. (2018). Rozmieszczenie usług jako podstawa rozpoznawania ośrodków podregionalnych w Polsce i ich hierarchii. Prace Komisji Geografii Przemysłu Polskiego Towarzystwa Geograficznego, 32(3), 237-251. https://doi.org/10.24917/20801653.323.15

\section{WSTĘP}

Przez podregionalne ${ }^{1}$ ośrodki obsługi rozumie się miasta, w których koncentrują się takie usługi, które w warunkach polskich mogą znajdować się w kilku miastach województwa, ale nie w każdym mieście powiatowym, ze względu na niepodzielność ekonomiczną, techniczną lub organizacyjną. Nazwano je ośrodkami poziomu podregionalnego (w skrócie podregionalnymi). Usługi rozumie się tu szeroko, jako świadczące je instytucje, a także obiekty, w niektórych przypadkach trwalsze od instytucji zarządzających nimi (np. stadiony).

Przemiany cywilizacyjne wpłynęły na zmiany w hierarchicznym modelu sieci osadniczej W. Christallera (Domański, 2006), ale aparat pojęciowy i wiele prawidłowości zachowuje aktualność (Fujita, Krugman, Mori; 1999, Zaborowski, 2014). Rodzi się pytanie, w jakim stopniu prawidłowości dotyczą nadal koncentracji usług w ośrodkach hierarchicznych. Pytanie to dotyczy zwłaszcza Polski i poziomu podregionalnego. Tu bowiem na lokalizacje usług tego właśnie poziomu wpływały nie tylko zmiany ustrojowe, a później fundusze Unii Europejskiej (jak w wielu innych państwach), ale i dwukrotne zmiany podziału administracyjnego - w latach 1975 i 1999.

Sieć osadniczą, ograniczoną do już ustalonych w Koncepcji przestrzennego zagospodarowania kraju 2030 (Koncepcja..., 2011) ośrodków regionalnych, badał Ł. Zaborowski (2014), lecz bez zakresu ich funkcji. Ośrodki subregionalne były przedmiotem projektu badawczego Subregionalne bieguny wzrostu w kontekście transformacji gospodarczej, reformy administracyjnej i gospodarki opartej na wiedzy, w którym rozpoznano ośrodki według kilku kryteriów, ale nie wyposażenia w usługi. Badane było też występowanie ośrodków subregionalnych w strategiach rozwoju województw (Suchta, Drońska, Celmer, 2007; Dziemianowicz, Szlachta, Szmigiel-Rawska, 2011). Subregionalne ośrodki wzrostu badano w związku z reformą terytorialnej organizacji kraju, gdy część miast straciła status stolicy województwa (Dziemianowicz, Szlachta, Szmigiel-Rawska, 2011), a także w ramach prac nad koncepcją przestrzennego zagospodarowania kraju (KPZK) (Korcelli i in., 2010).

Większość ośrodków podregionalnych to miasta średnie. A. Runge (2012) analizowała metodologiczne problemy badania tych miast w Polsce, uznając liczbę badań na ich temat za zbyt małą jak na ich rolę w krajowej sieci osadniczej. D. Sokołowski (2005), bazując na zatrudnieniu według REGON, sklasyfikował miasta duże i średnie według wskaźników węzłowości i centralności. Sieci osadnicze niektórych województw badano m.in. w związku z pracami nad dokumentami planistycznymi - strategią lub planami

${ }^{1}$ Termin ten (bardziej polski) autorzy stosują odnośnie do ośrodków obsługi, dla odróżnienia od terminu „subregionalny”, powszechnie obecnie używanego, przeważnie w znaczeniu szerszym. 
zagospodarowania przestrzennego województwa (PZPW). Delimitacje obszarów obsługiwanych przez ośrodki subregionalne były badane metodą grawitacji i potencjału w województwie małopolskim (Guzik i in., 2010) i pomorskim (Guzik, Działek, Plaza, Kołoś, 2012).

Tematykę ośrodków subregionalnych podejmowali też m.in. J. Dębski (2003) oraz K. Heffner i P. Gibas (2015). Rośnie liczba publikacji poświęconych badaniom usług, zwłaszcza ich poszczególnych rodzajów (np. Powęska, 2000; Kłosowski, Runge, 2002; Guzik, Kołoś, Panecka, Wiedermann, 2015). Pojawiła się np. tematyka centrów handlowych (m.in. Wilk, 2003; Heffner, Twardzik, 2013) oraz usług związanych z kulturą (m.in. Namyślak, 2013; Środa-Murawska, Szymańska, 2014). Ujęcia kompleksowe występują rzadziej, dotycząc m.in. wyposażenia w usługi, przeważnie wszystkich poziomów łącznie, ocenianych wskaźnikami (Noworól, 2010; Czapiewski, Janc, 2012; Ilnicki, 2014). J. Sołtys (2013) badał hierarchię małych miast w Polsce Północnej jako ośrodków usługowych na podstawie występujących tam usług.

Wobec braku badań ośrodków podregionalnych w Polsce, definiowanych poprzez zestawy usług zlokalizowanych w nich lub pożądanych, problematykę tę podjęto w 2015 roku (Sołtys, 2016). Kontynuacją tych badań były badania tu prezentowane. Uwzględniły one aktualniejsze dane, szerszy ich zakres i analizę większej liczby usług, prowadzącą do realizacji pierwszego z poniższych celów, a także analizę rozmieszczenia ośrodków. Celem badań było:

1. Określenie usług typowych dla poziomu podregionalnego.

2. Rozpoznanie koncentracji tych usług, tworzonych przez nie ośrodków i ich rozmieszczenia.

3. Ocena, w jakim stopniu występują prawidłowości hierarchicznego modelu lokalizacji usług.

Ostatni cel można zdekomponować na szukanie odpowiedzi na pytania: W jakim stopniu badane usługi koncentrują się w ośrodkach? Czy i jak są zróżnicowane ośrodki podregionalne, jakie można wyodrębnić ich typy (klasy)? Jakie są ich przedziały wielkości? Celem nie było natomiast rozpoznanie wszystkich usług poziomu podregionalnego. Badania objęły obszar (zwany dalej badanym obszarem) poza miastami wojewódzkimi i obszarami funkcjonalnymi miast wojewódzkich metropolitalnych, których listę zaczerpnięto z Koncepcji... (2011), a granice podano za P. Śleszyńskim (2013).

Jako metody badawcze zastosowano:

- klasyfikację (do badania zróżnicowania ośrodków) na podstawie liczby typowych usług i kombinacji ich rodzajów, jak w badaniach z 2015 roku, wzbogacając o dodatkowe podklasy;

- analizy kartograficzne (do badania rozmieszczenia ośrodków) z wykorzystaniem metody grafów opisanej przez Ł. Zaborowskiego (2014).

Źródłami informacji były: wyszukiwarki internetowe i Bank danych lokalnych GUS (Bank..., 2017).

\section{ANALIZA USŁUG - TWORZENIE LISTY TYPOWYCH USŁUG PODREGIONALNYCH}

W celu ustalenia listy usług typowych dla poziomu podregionalnego dokonano analizy liczebności ogółem i według województw usług uwzględnionych w 2015 roku i niektórych innych. 
Sądy okręgowe występują w 25 miastach poza miastami wojewódzkimi i ich obszarami funkcjonalnymi. Są to, z wyjątkiem Świdnicy, byłe miasta wojewódzkie (Lista sądów..., 2015). W tych samych miastach są prokuratury okręgowe, z jednym wyjątkiem - zamiast w Kaliszu - w Ostrowie Wielkopolskim (Prokuratura ..., 2017). Aby uprościć późniejszą klasyfikację, tylko jedną z tych instytucji, o większej liczbie użytkowników - sądy okręgowe - uwzględniono na liście typowych usług podregionalnych. Specyfiką tych instytucji jest urzędowa rejonizacja i rzadki kontakt z nimi, w dużym zakresie wymuszony prawem, niezależny od warunków dostępności z miejsca zamieszkania. Sądy okręgowe można zaliczyć do typowych usług podregionalnych, mimo że poza stolicami województw brak ich w trzech województwach. Są to bowiem najmniejsze województwa, a lubuskie ma dwa sądy okręgowe, lecz i dwie stolice.

Szpitale również są usługą, z której korzystanie jest wymuszone (stanem zdrowia i troską o nie). Za reprezentatywne dla poziomu podregionalnego uznano 40 szpitali, które posiadały II poziom referencyjności w okresie obowiązywania rozporządzenia w sprawie krajowej sieci szpitali oraz te, które spełniają określone w nim warunki (poza tym, że jest to szpital wojewódzki), czyli udzielają, obok świadczeń zdrowotnych typowych dla szpitali powiatowych, świadczenia z co najmniej czterech z następujących specjalności: kardiologii, neurologii, dermatologii, patologii ciąży i noworodka, okulistyki, laryngologii, chirurgii urazowej, urologii, neurochirurgii, chirurgii dziecięcej, chirurgii onkologicznej. Takich szpitali rozpoznano 18, przy czym badano tylko szpitale w miastach, w których jest co najmniej jedna inna usługa reprezentatywna dla poziomu podregionalnego. Szpitale te nie są jednorodne, co wynika z przyjętej definicji. Co najmniej cztery, a często więcej specjalności z wymienionych 11, daje różne kombinacje.

Przyjęcie jako kryterium węższej listy specjalności bez wyboru dałoby węższą listę jednorodnych szpitali, ale niekoniecznie byłoby to metodycznie lepsze. Zakres świadczeń zależy bowiem od skali zapotrzebowania na danym terenie, które jest zróżnicowane przestrzennie. Zależy też od uwarunkowań kadrowych, lokalowych i sprzętowych, przy czym te dwa ostatnie można sprowadzić do finansowych. Widać tendencję zwiększania przez szpitale powiatowe zakresu świadczeń specjalistycznych. Szpitale nie mają rejonizacji. Można założyć, że znaczna część pacjentów korzysta ze szpitala o najlepszej dostępności z miejsca zamieszkania, choć bywają i inne kryteria wyboru, np. opinia o jakości świadczonych usług.

W odróżnieniu od powyższych usług, korzystanie z innych dalej analizowanych jest fakultatywne i może zależeć od odległości, czasu i warunków dostępu z miejsca zamieszkania do danej usługi.

Filharmonie na badanym obszarze występują w liczbie ośmiu. Zlokalizowane są w pięciu województwach. Jest to zatem usługa poziomu regionalnego, a nie podregionalnego, skoro aż w 11 województwach nie występuje poza stolicą województwa (ryc. 1) (Filharmonie..., 2017).

Teatry są różnego rodzaju: dramatyczne, muzyczne, tańca i ruchu, lalkowe, prywatne i inne (Wyszukiwarka teatrów..., 2017). Uznano, iż pod względem tych rodzajów nie stanowią wobec siebie alternatywy i należy analizować je odrębnie. Teatrów dramatycznych jest na badanym obszarze 16, ale zlokalizowanych tylko w 11 województwach (ryc. 1). Teatry lalek są w 12 miejscowościach, w tym w ośmiu miastach powiatowych (z których tylko pięć spełnia warunki ośrodków podregionalnych, choćby niepełnych). Teatrów tańca jest osiem, w tym sześć w miastach powiatowych, z których pięć jest dalej klasyfikowanych. Nie uwzględniono instytucji określonych w wyszukiwarce 
(Wyszukiwarka teatrów..., 2017) jako teatry inne, ponieważ są to głównie zespoły amatorskie działające w domach kultury, ich trwałość jest niepewna. Analizowane teatry uznano za usługi poziomu regionalnego, dramatyczne - na granicy z poziomem podregionalnym. W dalszych analizach uwzględniono teatry dramatyczne i filharmonie jako usługi wzbogacające ośrodki, ale nie niezbędne, aby uznać dany ośrodek za podregionalny.

Kina multipleksowe tworzone przez wyspecjalizowane sieci (Cinema 3D, Cinema City, Helios, Multikino) uznano w 2015 roku za reprezentatywne dla poziomu podregionalnego ze względu na rozmieszczenie i liczbę. Liczba miast z tymi kinami wzrosła z 30 w 2014 roku do 40 w 2016 roku (Sieci multipleksów..., 2017). Modernizowane są też inne kina i wyposażane w nowoczesny sprzęt, w związku z czym uwzględniono też kilka kin spoza powyższych sieci, przyjmując jako kryterium posiadanie projektorów cyfrowych, dźwięku wielokanałowego i minimum dwóch sal (Planet Cinema..., 2017; Cinema N3D, 2018). Ta liczba sal jako kryterium może być dyskusyjna, ale taka jest najmniejsza liczba sal multipleksów sieciowych - w Koninie.

Wyższe uczelnie z kolei są usługą o malejącym znaczeniu w wielu miastach z powodu malejącej liczby studentów i zaprzestaniu działalności niektórych placówek, co ilustrują tab. 1-3. W latach 2012-2016 aż 18 miast przestało być siedzibą wyższej uczelni, a 37 - jednostki zamiejscowej. Jest to konsekwencją niżu demograficznego. Można dopatrywać się też dodatkowych przyczyn. Po upowszechnieniu się wykształcenia wyższego, zwłaszcza o kierunkach najbardziej popularnych, nie daje już ono takich szans na pracę, jak w latach dziewięćdziesiątych.

Pojawia się problem, jak traktować uczelnie, a zwłaszcza ich jednostki zamiejscowe, o niewielkiej liczbie studentów, przeważnie malejącej. Ustalono arbitralnie, że jako miasta z wyższymi uczelniami uwzględniane będą te, w których w 2016 roku studiowało minimum 200 studentów. Zróżnicowano je, przyjmując jako granicę liczbę 1000 studentów.

Tab. 1. Wyższe uczelnie w miastach badanego obszaru w latach 2012-2016

\begin{tabular}{|l|c|c|c|c|c|c|c|}
\hline \multirow{2}{*}{$\begin{array}{l}\text { Miasta, w których są lub } \\
\text { były }\end{array}$} & \multicolumn{2}{|c|}{ Jednostki } & \multicolumn{2}{c|}{ Miasta } & \multicolumn{3}{c|}{ Studenci } \\
\cline { 2 - 8 } & 2012 & 2014 & 2012 & 2014 & \multicolumn{2}{|c|}{ w tys. } & dynamika \\
\cline { 4 - 8 } & 141 & 115 & 84 & 66 & 135,1 & 83,9 & 64,9 \\
\hline Siedziby uczelni & 194 & 113 & 120 & 87 & 21,5 & 8,7 & 40,4 \\
\hline $\begin{array}{l}\text { Tylko jednostki } \\
\text { zamiejscowe }\end{array}$ & & & & & $2014-100)$ \\
\hline
\end{tabular}

Źródło: Bank... (2017) i obliczenia własne

Tab. 2. Zmiany w miastach z wyższymi uczelniami na badanym obszarze w latach 2012-2016

\begin{tabular}{|l|c|c|}
\hline \multicolumn{1}{|c|}{ Wyszczególnienie } & Liczba miast & $\begin{array}{c}\text { Dynamika liczby studentów } \\
(2012-100)\end{array}$ \\
\hline Miasta ze wzrostem liczby studentów & 14 & 119,5 \\
\hline Miasta ze spadkiem liczby studentów & 145 & 60,9 \\
\hline $\begin{array}{l}\text { Miasta z całkowitą utratą uczelni lub jednostki } \\
\text { zamiejscowej }\end{array}$ & 34 & $\mathrm{x}$ \\
\hline
\end{tabular}

Źródło: Bank... (2017) i obliczenia własne 
Tab. 3. Zmiany w miastach badanego obszaru według liczby studentów w latach 2012-2016

\begin{tabular}{|c|c|c|c|c|c|c|}
\hline \multicolumn{2}{|c|}{ Wyszczególnienie } & \multicolumn{2}{|c|}{ Jednostki } & \multicolumn{2}{|c|}{ Miasta } & \multirow{2}{*}{$\begin{array}{c}\text { Studenci } \\
\text { Dynamika }\end{array}$} \\
\hline & & 2012 & 2016 & 2012 & 2016 & \\
\hline \multirow{2}{*}{$\begin{array}{l}\text { Studentów: } \\
>1000\end{array}$} & siedziby & 89 & 84 & 41 & 41 & \multirow{2}{*}{$67,8^{\mathrm{a}}$} \\
\hline & jedn. zam. & 65 & 38 & 30 & 21 & \\
\hline \multirow{2}{*}{ 200-999 } & siedziby & 35 & 26 & 27 & 21 & \multirow{2}{*}{$63,7^{\mathrm{b}}$} \\
\hline & jedn. zam. & 55 & 41 & 32 & 30 & \\
\hline \multirow{2}{*}{$<200$} & siedziby & 17 & 5 & 16 & 5 & \multirow{2}{*}{13,9} \\
\hline & jedn. zam. & 74 & 34 & 58 & 31 & \\
\hline
\end{tabular}

a Wzrost w trzech miastach ${ }^{\mathrm{b}}$ Wzrost w ośmiu miastach

Źródło: Bank... (2017) i obliczenia własne

Jako reprezentatywne wyspecjalizowane duże obiekty handlowe przyjęto obiekty branży: materiały budowlane, artykuły wyposażenia domu i ogród. Na badanym obszarze największe sieci miały następujące liczby obiektów: Castorama - 24, Leroy Merlin - 10, Nomi - 14, OBI - 10, Praktiker - 4 (Lista sieci ..., 2018). Te 62 obiekty obecne są w 41 miastach. Liczba ta uzasadniałaby zaliczenie ich do typowych usług podregionalnych, gdyby nie fakt, że są i inne sieci, o większej liczbie obiektów, głównie w mniejszych miejscowościach: Bricomarché - 126 obiektów (statystycznie prawie w co drugim powiecie) oraz Grupa PSB, w tym sklepy „Mrówka”, posiadająca ponad 500 obiektów, także w gminach wiejskich. Produkty w tych sieciach są podobne jak w większych, lecz większe sieci dają większy wybór. Z tego powodu nie zaliczono omawianych obiektów handlu do typowych usług podregionalnych.

Do listy typowych usług podregionalnych mogą pretendować też odpowiedniej wielkości sale sportowo-widowiskowe, stadiony i aquaparki. Problemem jest ustalenie tych wielkości. Można je ustalić empirycznie, jako odpowiadające takim obiektom, które w zdecydowanej większości województw obecne są poza miastem wojewódzkim w mniej niż połowie (albo np. jednej trzeciej) miast powiatowych. W planie zagospodarowania przestrzennego województwa małopolskiego (Plan..., 2003) określono minimalną wielkość stadionu na 10 tys. miejsc. Wielkość ta wymagałaby weryfikacji, np. w sposób wyżej wskazany. Uznano jednak, że różnice wielkości nie pociągają różnic jakościowych, a powyższe obiekty, różnej wielkości, istnieją w ośrodkach różnych poziomów.

Jako usługi typowe dla poziomu podregionalnego, definiujące te ośrodki, pozostają zatem: sądy okręgowe, szpitale według podanej definicji, dalej zwane wielospecjalistycznymi, wyższe uczelnie i kina multipleksowe, co potwierdza słuszność doboru tych usług w badaniach w 2015 roku i ułatwia porównanie wyników.

\section{OŚRODKI PODREGIONALNE - ROZPOZNANIE I KLASYFIKACJA}

Tylko 23 miasta posiadają zestaw czterech usług definiujących ośrodek podregionalny. Nazwano je ośrodkami podregionalnymi pełnymi (tab. 4, klasa 1). Podobnie jak w poprzednim badaniu, sklasyfikowano pozostałe ośrodki, zwane podregionalnymi niepełnymi, według liczby typowych usług: trzech (20 miast) lub dwóch (26 miast). Kombinacje tych usług dają podklasy. Wprowadzono też podklasy kolejnych rzędów przez 
Tab. 4. Klasyfikacja ośrodków podregionalnych

\begin{tabular}{|c|c|c|c|c|c|}
\hline \multirow[b]{2}{*}{$\begin{array}{l}\text { Klasa, } \\
\text { pod- } \\
\text { klasa }\end{array}$} & \multirow[b]{2}{*}{$\begin{array}{l}\text { Usługi } \\
\text { typowe }\end{array}$} & \multirow[b]{2}{*}{ Usługi wzbogacające } & \multirow[b]{2}{*}{$\begin{array}{l}\text { Liczba } \\
\text { studentów }\end{array}$} & \multicolumn{2}{|l|}{ Miasta } \\
\hline & & & & Nazwy & $\begin{array}{l}\text { Ludność } \\
\text { w tys. - } \\
\text { przedział } \\
\text { i średnia }\end{array}$ \\
\hline \multirow{5}{*}{1} & \multirow{5}{*}{$\begin{array}{l}\text { Sąd, } \\
\text { szpital, } \\
\text { kino, } \\
\text { uczelnia }\end{array}$} & $\begin{array}{l}\text { Filharmonia } \\
\text { i teatr dramatyczny }\end{array}$ & $\geqslant 1000$ & $\begin{array}{l}\text { Częstochowa, Koszalin, Słupsk, } \\
\text { Jelenia Góra, Kalisz }\end{array}$ & $\begin{array}{l}81-230^{a} \\
123\end{array}$ \\
\hline & & Filharmonia & \multirow{3}{*}{$\geqslant 1000$} & Łomża & 63 \\
\hline & & Teatr dramatyczny & & $\begin{array}{l}\text { Bielsko-Biała, Elbląg, Legnica, } \\
\text { Płock, Radom, Siedlce, Tarnów }\end{array}$ & $\begin{array}{l}77-217 \\
132\end{array}$ \\
\hline & & & & $\begin{array}{l}\text { Konin, Krosno, Nowy Sącz, } \\
\text { Piotrków Trybunalski, Przemyśl, } \\
\text { Suwałki, Włocławek, Zamość }\end{array}$ & $\begin{array}{l}47-114 \\
74\end{array}$ \\
\hline & & & $<1000$ & Ostrołęka, Świdnica & $\begin{array}{l}53-59 \\
56\end{array}$ \\
\hline \multirow{2}{*}{$2 a$} & \multirow{2}{*}{$\begin{array}{l}\text { Sąd, } \\
\text { szpital, } \\
\text { uczelnia }\end{array}$} & & $\geqslant 1000$ & Tarnobrzeg & 48 \\
\hline & & & $<1000$ & Sieradz & 43 \\
\hline \multirow{5}{*}{$2 b$} & \multirow{5}{*}{$\begin{array}{l}\text { Kino, } \\
\text { szpital, } \\
\text { uczelnia }\end{array}$} & $\begin{array}{l}\text { Filharmonia } \\
\text { i teatr dramatyczny }\end{array}$ & $\geqslant 1000$ & Wałbrzych & 117 \\
\hline & & \multirow{2}{*}{ Teatr dramatyczny } & & Gniezno & 69 \\
\hline & & & $<1000$ & Grudziądz & 96 \\
\hline & & & $\geqslant 1000$ & $\begin{array}{l}\text { Leszno, Nysa, Oświęcim, Piła, } \\
\text { Stalowa Wola }\end{array}$ & $\begin{array}{l}39-74 \\
57\end{array}$ \\
\hline & & & $<1000$ & $\begin{array}{l}\text { Bełchatów, Biała Podlaska, Głogów, } \\
\text { Ełk, Inowrocław, Kłodzko, Puławy, } \\
\text { Stargard Szczeciński, Starogard } \\
\text { Gdański, Tomaszów Mazowiecki }\end{array}$ & $\begin{array}{l}28-75 \\
57\end{array}$ \\
\hline \multirow{3}{*}{ 3a } & \multirow{3}{*}{$\begin{array}{l}\text { Szpital, } \\
\text { uczelnia }\end{array}$} & Teatr dramatyczny & $<1000$ & Cieszyn & 36 \\
\hline & & & $\geqslant 1000$ & $\begin{array}{l}\text { Chełm, Chojnice, Ciechanów, } \\
\text { Jarosław, Jasło, Nowy Targ, } \\
\text { Ostrowiec Świętokrzyski, Racibórz, } \\
\text { Sanok, Skierniewice, Żary }\end{array}$ & $\begin{array}{l}33-72 \\
46\end{array}$ \\
\hline & & & $<1000$ & $\begin{array}{l}\text { Ełk, Gryfice, Inowrocław, } \\
\text { Jastrzębie, Jaworzno, Kołobrzeg, } \\
\text { Kościerzyna, Kutno, Ostrów } \\
\text { Wielkopolski, Sandomierz, Wałcz, } \\
\text { Żyrardów }\end{array}$ & $\begin{array}{l}17-90 \\
53\end{array}$ \\
\hline $3 b$ & $\begin{array}{l}\text { Kino, } \\
\text { uczelnia }\end{array}$ & & $<1000$ & Lubin, Zduńska Wola & $\begin{array}{l}43-73 \\
58\end{array}$ \\
\hline \multirow[b]{2}{*}{$3 c$} & \multirow{2}{*}{$\begin{array}{l}\text { Kino, } \\
\text { szpital }\end{array}$} & Filharmonia & - & Rybnik & 140 \\
\hline & & & - & $\begin{array}{l}\text { Kędzierzyn-Koźle, Starachowice, } \\
\text { Zgorzelec }\end{array}$ & $\begin{array}{l}32-63 \\
48\end{array}$ \\
\hline
\end{tabular}

a Pogrubiono minima i maksima dla całych klas

Źródło: opracowanie własne na podstawie Bank... (2017) oraz Filharmonie... (2017), Lista sądów... (2015), Lista sieci handlowych... (2017), rozporządzenie w sprawie krajowej sieci szpitali, Sieci multipleksów... (2017); Wyszukiwarka teatrów... (2017)

uwzględnienie filharmonii i teatrów oraz zróżnicowanej liczby studentów w uczelniach (tab. 4, ryc. 1). Wszystkich kombinacji jest dużo, ale na poziomie podklas I rzędu najliczniejsza jest podklasa 3a, zawierająca 21 ośrodków podregionalnych niepełnych ze szpitalem i uczelnią, z czego w 11 studiowało w 2016 roku co najmniej 1000 studentów. 
Liczna jest też podklasa 2a (szpital, uczelnia, kino) zawierająca 18 miast na 20 tworzących klasę 2, z których w ośmiu (44\% podklasy 2a) liczba studentów przekracza 1000. Najmniej liczne, dwuelementowe, są podklasy 2a i 3b.

Najpowszechniejszą usługą w całym zbiorze 70 ośrodków jest szpital wielospecjalistyczny. Brak go tylko w Lubinie i Zduńskiej Woli. Miast z uczelniami jest 67 (96\% zbioru), z kinami multipleksowymi - 47 (67\%), z sądami okręgowymi - 25 (36\%).

Prawie wszystkie ośrodki podregionalne pełne prócz Świdnicy to byłe miasta wojewódzkie. Miasta takie stanowią też podklasę 2a. Po trzy byłe miasta wojewódzkie są w podklasie $2 \mathrm{~b}$ i $3 \mathrm{a}$.

Większość ośrodków podregionalnych pełnych (12, co stanowi 52\% ich liczby) posiada teatry dramatyczne, sześć (26\%) - filharmonie. Najlepiej wyposażone w instytucje kultury spoza dawnych miast wojewódzkich są Rybnik, Grudziądz i Gniezno, posiadające filharmonię (Rybnik) lub teatr dramatyczny oraz kino multipleksowe. Najmniejszym miastem mającym filharmonię jest Łomża (63 tys. ludności), najmniejszym miastem z teatrem dramatycznym jest Cieszyn (36 tys. mieszkańców), niebędący przed 1975 rokiem miastem wojewódzkim.

Badane ośrodki są zróżnicowane pod względem liczby ludności (tab. 4). Największym jest Częstochowa (230 tys. osób), najmniejszym - Gryfice (17 tys. osób). Średnia całego zbioru to 70 tys. mieszkańców, klasy I - 100, II - 62, III - 49 tys. osób.

W dużym stopniu występują prawidłowości typowe dla hierarchicznego modelu obsługi. Koncentracja nie jest pełna, ale odstępstwa są niewielkie. Ich przykładem są kina multipleksowe w ośrodkach klasy 3c. Gdyby dwa z tych kin były zlokalizowane w ośrodkach obecnej klasy 2a, byłoby o dwa więcej ośrodków podregionalnych pełnych. Lokalizacja kin zależy od uwarunkowań rynku i strategii inwestorów, ale też od polityki władz prowadzących instytucje kultury - niektóre lokalne kina są modernizowane. Brak kin w Tarnobrzegu i Sieradzu, byłych miastach wojewódzkich, można tłumaczyć bliskością kin w Stalowej Woli i Zduńskiej Woli. Proces inwestowania w kina trwa, zatem wymienione miasta mają szansę awansu na ośrodki podregionalne pełne, natomiast ośrodki klasy 3a, po zrealizowaniu kina multipleksowego, awansowałyby do klasy 2b. Największe ośrodki bez kina multipleksowego to Ostrów Wielkopolski i Ostrowiec Świętokrzyski (blisko są takie kina w Kaliszu i Starachowicach), najmniejszym ośrodkiem z kinem jest Kłodzko (28 tys. ludności).

Poza powyższymi możliwości podwyższenia klas ocenia się jako niewielkie. Raczej nie przybędzie uczelni, a lokalizacje sądów okręgowych można uznać za najbardziej stabilne spośród analizowanych usług. Możliwe są oczywiście ich zmiany decyzją władz centralnych, ale po ewentualnej zmianie oczekiwać należałoby długookresowej stabilności. Mogą natomiast pojawić się nowe ośrodki podregionalne niepełne za sprawą nowych kin w miastach, w których istnieją i przetrwają uczelnie lub w których są albo rozwiną się szpitale wielospecjalistyczne.

Można też spodziewać się zaniku niektórych ośrodków podklasy 3a i 3b oraz spadku z klasy 2 do 3, a nawet z 1 do 2 z powodu dalszych spadków liczby studentów.

\section{ROZMIESZCZENIE OŚRODKÓW PODREGIONALNYCH}

Rozmieszczenie rozpoznanych ośrodków jest nierównomierne (ryc. 1). Najwięcej ośrodków podregionalnych pełnych (cztery) ma województwo mazowieckie. Brak takich ośrodków w trzech województwach wynika z braku sądów okręgowych poza 
Ryc. 1. Ośrodki podregionalne pełne i niepełne - klasyfikacja

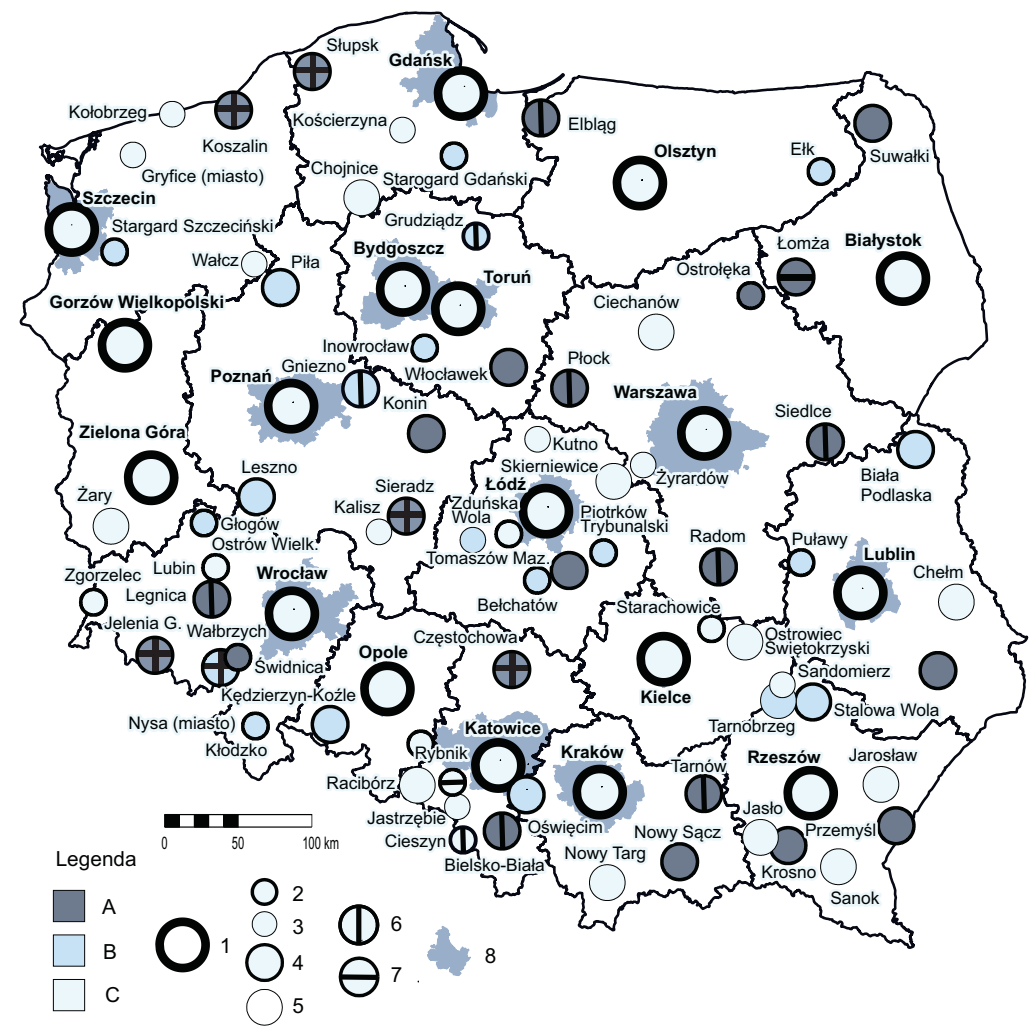

Ośrodki podregionalne: A - pełne, B - niepełne z 3 typowymi usługami, C - niepełne z 2 typowymi usługami. 1 - miasta wojewódzkie. Ośrodki podregionalne: 2, 4 - z kinem multipleksowym, 3, 5 - bez takiego kina, 2, 3 - z liczbą studentów 200-999, 4, 5 - z liczbą studentów $\geqslant 1000,6$ - z teatrem dramatycznym, 7 - z filharmonią, 8 - obszary funkcjonalne miast wojewódzkich metropolitalnych według Koncepcji ... (2011) i Śleszyńskiego (2013).

Źródło: opracowanie własne

miastami wojewódzkimi. Zróżnicowanie zagęszczenia wszystkich ośrodków wynika prawdopodobnie z gęstości zaludnienia.

W badaniu rozmieszczenia ośrodków posłużono się metodą graficzną opisaną przez Ł. Zaborowskiego (2014) dla ośrodków podregionalnych z teatrami (ryc. 2) i podregionalnych pełnych (ryc. 3). W obszar Polski wpisano trójkąty, którego wierzchołki wyznaczały powyższe ośrodki oraz miasta wojewódzkie, również pełniące funkcje podregionalne i posiadające teatry. Wykreślając trójkąty, przyjęto zasadę, że połączenia nie mogą się przecinać. W układzie czterech bądź więcej ośrodków, gdzie połączenie można było poprowadzić na więcej niż jeden sposób, wprowadzano najkrótsze połączenia. Kiedy odległości były takie same, wykreślano to połączenie, które tworzy dwa trójkąty o podobnej powierzchni. W ten sposób każdemu ośrodkowi przypisany został teoretyczny region w kształcie sześciokąta. Gęstość linii oraz powierzchnia 
Ryc. 2. Odległości między sąsiednimi ośrodkami podregionalnymi z teatrami (w km)

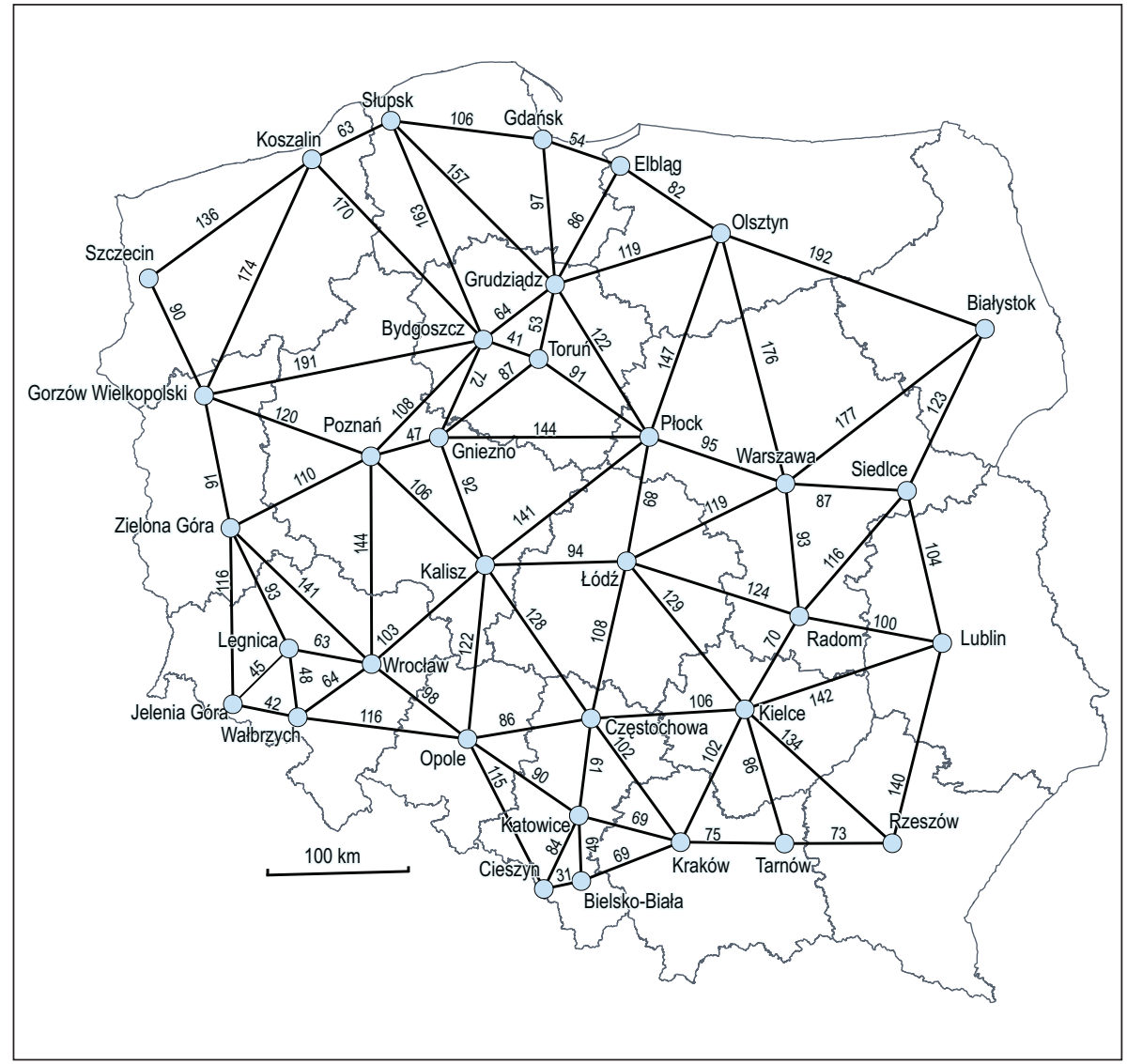

Źródło: opracowanie własne

trójkątów wyliczona według odległości w linii prostej od poszczególnych miejscowości informuje o gęstości ośrodków. Dla obszarów przygranicznych założono, że zasięg regionu węzłowego wyznacza połowa odległości między sąsiednimi ośrodkami bądź odległość od granicy państwa. Połączeń ośrodków z granicą nie zaznaczano na rysunku.

W analizie rozmieszczenia ośrodków z teatrami rysują się zarówno ich skupiska, jak i obszary o małej gęstości sieci. Najmniejsze odległości pomiędzy węzłami grafu występują w przypadku Cieszyna i Bielska-Białej (31 km), Torunia i Bydgoszczy (41 km) oraz Jeleniej Góry i Wałbrzycha (42 km). Występują ponadto dwa skupiska ośrodków: w regionie dolnośląskim (Jelenia Góra, Wałbrzych, Legnica i Wrocław), gdzie odległość między ośrodkami nie przekracza 65 km, oraz na Kujawach (Bydgoszcz, Grudziądz i Toruń). Innymi ośrodkami, tworzącymi układy bi- i tripolarne, są: Poznań-Gniezno, Katowice-Bielsko-Biała-Kraków, Gdańsk-Elbląg, Koszalin-Słupsk. Można też wyróżnić historyczny układ łańcuchowy nawiązujący do układu via regia: Cieszyn-Bielsko-Biała-Kraków-Tarnów-Rzeszów, gdzie odległości nie przekraczają 75 km (ryc. 2). Najmniejsze zagęszczenie występuje na peryferiach, szczególnie na północy kraju. Największą powierzchnię mają trójkąty: Warszawa-Olsztyn-Białystok (14 $218 \mathrm{~km}^{2}$ ) oraz Bydgoszcz-Gorzów Wielkopolski-Koszalin (13 658 km²). Trzecim pod względem 
Ryc. 3. Odległości między sąsiednimi ośrodkami podregionalnymi pełnymi (w km)

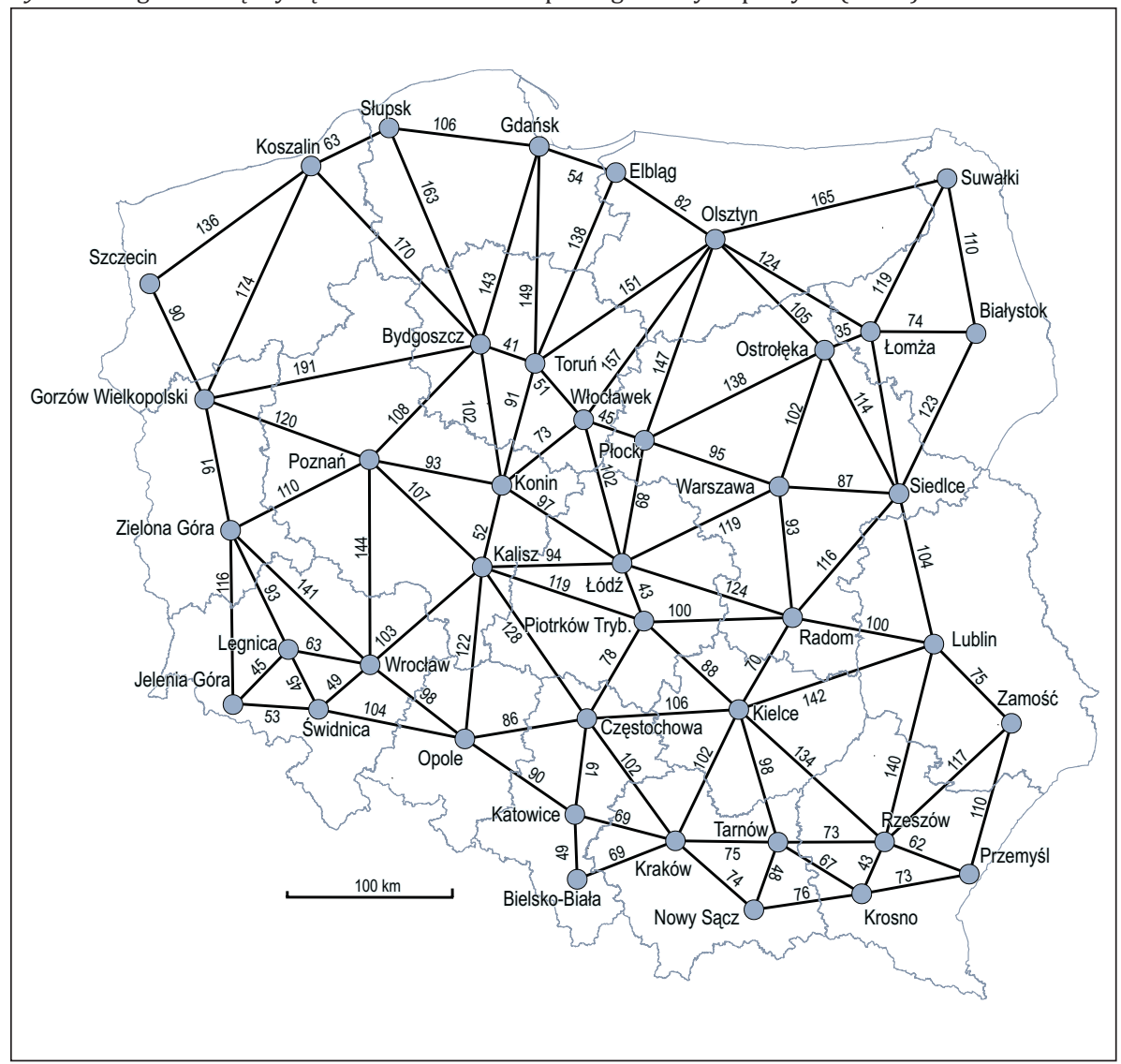

Źródło: opracowanie własne

wielkości jest trójkąt: Kielce-Lublin-Rzeszów $\left(8311 \mathrm{~km}^{2}\right)$. Są to zatem obszary peryferyjne, gdzie w wyniku procesów historycznych nie wykształciły silne się ośrodki.

W porównaniu z siecią teatrów układ ośrodków podregionalnych pełnych obejmuje większą część Polski. Jednakże i w tym przypadku widać dysproporcje przestrzenne w ich lokalizacji (ryc. 3). Najmniejsze odległości między miastami wykazują: Ostrołęka i Łomża (35 km), Bydgoszcz i Toruń (41 km), Łódź i Piotrków Trybunalski (43km), Włocławek i Płock (45 km) oraz region Jelenia Góra-Legnica-Świdnica-Wrocław (maksymalna odległość $63 \mathrm{~km}$ ) i obszar na południu od Katowic po Przemyśl (maksymalna odległość $76 \mathrm{~km}$ ). Obszary o najniższej gęstości występują na północy i zachodzie kraju. Największe powierzchnie trójkąta, a więc i największe odległości między ośrodkami, są na obszarach: Bydgoszcz-Gorzów Wielkopolski-Koszalin $\left(13658 \mathrm{~km}^{2}\right)$, Kielce-LublinRzeszów (8311 km²), Słupsk-Gdańsk-Bydgoszcz (7470km²), Olsztyn-Suwałki-Łomża $\left(7355 \mathrm{~km}^{2}\right)$ oraz Poznań-Zielona Góra-Wrocław $\left(7227 \mathrm{~km}{ }^{2}\right)$.

W obu analizowanych sieciach ośrodkami najbardziej izolowanymi są Szczecin i Gorzów Wielkopolski na zachodzie oraz Suwałki i Białystok na wschodzie. Są to obszary przygraniczne. Pomimo procesu integracji europejskiej nie można przyjąć, iż ośrodki te mają powiązania z sąsiednimi ośrodkami poza granicą kraju (Dorocki, 2010). 


\section{WNIOSKI}

W porównaniu z badaniami z 2015 roku nie tylko zaktualizowano dane, ale również: zrezygnowano z nieaktualnego kryterium poziomu referencyjności szpitali, wprowadzono próg 200 studentów dla uwzględniania wyższych uczelni, wzięto pod uwagę tworzenie kin podobnych do multipleksów poprzez modernizację. Wiązało się to z rozszerzeniem zakresu źródeł, ale i z subiektywnością niektórych ustaleń. Wymaga dyskusji, czy w przyszłych badaniach nie zmienić kryterium dotyczącego kin na wyłącznie jakościowe (np. projektory cyfrowe i dźwięk wielokanałowy). Możliwe jest, że w miarę upowszechniania modernizacji nowoczesne kino stanie się, podobnie jak dawniej, usługą poziomu powiatowego.

W porównaniu z badaniami z 2015 roku przybyło 13 ośrodków, a ubyły dwa. Przyrosty spowodowane były powstaniem nowych multipleksów i uwzględnieniem specjalności szpitali posiadających dawniej I, a nie II poziom referencyjności. Przyczyną ubytków były: zaprzestanie działalności uczelni w Dębicy i spadek liczby studentów do 78 w Świnoujściu.

Niewielki jest zakres możliwych zmian odnośnie do usług tu analizowanych. Władze województwa jako podmiot polityki regionalnej mają bezpośredni wpływ na usługi przez siebie prowadzone, a inne - jeśli dysponują środkami na ich rozwój (np. szpitali, modernizację niektórych kin, np. będących częścią domów kultury). Władze mają też wpływ na nieanalizowane tu sale widowiskowo-sportowe oraz inne obiekty sportowe i rekreacyjne. Dlatego zasadne jest uwzględnienie w dalszych badaniach i tych obiektów, nawet gdyby wymagało to oparcia na ilościowym kryterium i znalezienia przedziału wielkości typowego dla poziomu podregionalnego, odróżniającego od poziomu powiatowego i regionalnego.

Szersza lista modelowych usług definiujących ośrodki podregionalne mogłaby być wykorzystywana w planowaniu i polityce regionalnej. W Niemczech ranga planistyczna ośrodków określa lokalizacje dóbr publicznych (Zaborowski, 2014). Natomiast w Polsce ośrodki tworzące hierarchię sieci osadniczej w PZPW rzadko są podstawą lokalizacji usług publicznych, a sama ranga ośrodków w większości planów stanowi nie tylko o obsłudze, ale i znaczeniu w rozwoju (Sołtys, 2017). Dlatego rekomenduje się ustalanie elementów sieci osadniczej w PZPW odrębnie jako niehierarchicznych ośrodków rozwoju, odrębnie - jako hierarchicznych ośrodków obsługi, zwłaszcza podregionalnych, z ewentualnym ich zróżnicowaniem, zależnie od zestawu usług. Lokalizacja nowych usług podregionalnych (obiektów, urządzeń) w tych, a nie innych ośrodkach, mogłaby stanowić warunek konieczny finansowania ze środków publicznych lub w wersji łagodniejszej - dawać preferencje. Poza tym uznanie za podregionalny ośrodek obsługi dawałoby miastom wskazówki co do tworzenia warunków dla lokalizacji usług zarówno publicznych, jak i komercyjnych (teren w planach, infrastruktura, promocja). Konsekwentna koncentracja usług w ośrodkach mogłaby dawać następujące efekty:

- łączenie celów podróży, a więc mniej przejazdów (efekty społeczne, ekonomiczne, ekologiczne);

- kanalizacja ruchu - większe uzasadnienie dla modernizacji dróg i transportu publicznego;

- czytelność decyzji lokalizacji usług publicznych (według kryteriów racjonalnych, a nie politycznych). 
Jako przedmiot dalszych badań rekomenduje się rozpoznanie zasięgów obszarów obsługi ośrodków, a raczej poszczególnych usług, maksymalnych odległości i czasów przejazdu oraz liczby obsługiwanej ludności. Przedmiotem dalszych badań może być też szukanie odpowiedzi na następujące pytania dotyczące zestawu typowych (modelowych) usług definiujących ośrodki podregionalne (w tym obiektywizacja subiektywnie przyjętych niektórych kryteriów):

- Jak zdefiniować jako usługi podregionalne szpitale (czy odmiennie niż wzorując się na rozporządzeniu w sprawie krajowej sieci szpitali)?

- Jak definiować kina i czy z inną definicją będą to usługi podregionalne?

- Czy włączyć do listy obiekty handlu, sportu i rekreacji - które - w jakim przedziale wielkości i jak dojść do określenia tego przedziału?

Interesujące byłyby też międzynarodowe porównanie badanych zagadnień.

\section{Literatura}

\section{References}

Bank danych lokalnych GUS (2017, 20 października). Pozyskano z https://bdl.stat.gov.pl/BDL/ start

Cinema N3D (2018, 2 stycznia). Pozyskano z http://www.kino.nysa.pl/o-kinie

Czapiewski, K.Ł., Janc, K. (2012). Dostępność edukacji, jakość kształcenia i poziom wykształcenia mieszkańców a struktura funkcjonalna gmin województwa mazowieckiego. Mazowsze Studia Regionalne, 10, 33-51.

Dębski, J. (2003). Lokalne bieguny wzrostu w Polsce (według budżetów gmin i przedsiębiorczości prywatnej). Prace Komisji Geografii Przemysłu Polskiego Towarzystwa Geograficznego, 5, 31-58.

Domański, R. (2006). Gospodarka przestrzenna: Podstawy teoretyczne. Warszawa: Wydawnictwo Naukowe PWN.

Dorocki, S. (2010). Gospodarka regionów granicznych w procesie integracji europejskiej. Przedsiębiorczość-Edukacja, 6, 252-270.

Dziemianowicz, W., Szlachta, J., Szmigiel-Rawska, K. (red). (2011). Subregionalne bieguny wzrostu w Polsce. Warszawa: Uniwersytet Warszawski, Wydział Geografii i Studiów Regionalnych.

Filharmonie w Polsce (2017, 10 listopada). Pozyskano z http://www.individualis.pl/filarmonia. html

Fujita, M., Krugman, P., Mori, T. (1999). On the evolution of hierarchical urban systems. European Economic Review, 43(2), 209-251.

Guzik, R., Działek, J., Plaza, M., Kołoś, A. (2012). Czynniki i ograniczenia rozwoju miast województwa pomorskiego $w$ świetle relacji przestrzennych i dostępności komunikacyjnej. Gdańsk: Urząd Marszałkowski Województwa Pomorskiego.

Guzik, R., Kołoś, A., Panecka, M., Wiedermann, K. (2015). Stan i dostępność wybranych usług publicznych. W: R. Guzik, A. Kołoś (red.). Relacje funkcjonalno-przestrzenne między ośrodkami miejskimi i ich otoczeniem w województwie pomorskim. Gdańsk: Urząd Marszałkowski Województwa Pomorskiego, 115-148.

Guzik, R., Zborowski, A., Kołoś, A., Micek, G., Gwosdz, K., Trzepacz, P., Chaberko, T., Kretowicz, P., Ciechowski, M., Dej, M., Grad, N. (2010). Dostępność komunikacyjna oraz delimitacja obszarów funkcjonalnych. W: B. Domański, A. Noworól (red.). Małopolskie miasta - funkcje, potencjał i trendy rozwojowe. Kraków: Małopolskie Obserwatorium Polityki Rozwoju, 88-134.

Heffner, K., Gibas, P. (2015). Obszary funkcjonalne i ich zwiqzzki z zasieggiem oddziaływania ośrodków subregionalnych (na przykładzie województwa opolskiego). Opole: Wydawnictwo Uniwersytetu Opolskiego, 9-25.

Heffner, K., Twardzik, M. (2013). Społeczne oddziaływanie nowoczesnych centrów handlowo-usługowych na małe miasta w zewnętrznej strefie aglomeracji górnośląskiej. Studia Ekonomiczne, 144(13), 95-108. 
Ilnicki, D. (2014). Usługi w polskiej literaturze przedmiotu. Ujęcie chronologiczno-tematyczne. Space-Society-Economy, 13, 203-246.

Kłosowski, F., Runge, J. (2002). Usługi w mieście przygranicznym na przykładzie Cieszyna. Geographia. Studia et Dissertationes, 25, 74-91.

Koncepcja przestrzennego zagospodarowana kraju 2030 (2011). Warszawa: Ministerstwo Rozwoju Regionalnego.

Korcelli, P., Degórski, M., Drzazga, D., Komornicki, T., Markowski, T., Szlachta, J., Węcławowicz, G., Zaleski, J., Zaucha, J. (2010). Ekspercki projekt przestrzennego zagospodarowania kraju do roku 2033. Studia Komitetu Przestrzennego Zagospodarowania Kraju Polskiej Akademii Nauk, CXXVIII.

Lista sądów powszechnych (2015, 6 września). Pozyskano z https://bip.ms.gov.pl/pl/rejestry-i-ewidencje/lista-sadow-powszechnych

Lista sieci handlowych i usługowych (2017, 9 października). Pozyskano z http://www.lista.e-sieci. $\mathrm{pl}$ /20,Markety,Sklepy,i,Sklady,Budowlane.html

Namyślak, B. (2013). Ocena potencjału kulturalnego największych miast Polski. Wiadomości Statystyczne, 6, 23-38.

Noworól, A. (2010). Narzędzia poprawy jakości życia w miastach na przykładzie Małopolski. W: A. Noworól (red.). Jakość życia a procesy zarządzania rozwojem i funkcjonowaniem organizacji publicznych. T. 1. Kraków: Instytut Spraw Publicznych Uniwersytetu Jagiellońskiego.

Plan zagospodarowania przestrzennego województwa małopolskiego (2003). Kraków: Urząd Marszałkowski Województwa Małopolskiego.

Planet Cinema (2017, 20 października). Pozyskano z http://www.planetcinema.pl/elk/o-kinie/

Powęska, H. (2000). Regionalne zróżnicowanie rozwoju sfery usług w Polsce lat 90. W: S. Ciok, D. Ilnicki (red.). Przekształcenia regionalnych struktur funkcjonalno-przestrzennych, 5. Wrocław: Instytut Geograficzny Uniwersytetu Wrocławskiego, 341-349.

Prokuratora Krajowa (2017, 15 grudnia). Pozyskano z https://pk.gov.pl/jednostki-podlegle-1/ jednostki-podlegle-1.html

Rozporządzenie Ministra Zdrowia i Opieki Społecznej z dnia 22 grudnia 1998 r. w sprawie krajowej sieci szpitali oraz ich poziomów referencyjnych (Dz.U. z 1998 r., nr 164, poz. 1193).

Runge, A. (2012). Metodologiczne problemy badania miast średnich w Polsce. Prace Geograficzne, 129, 83-101.

Sieci multipleksów w Polsce (2017, 15 listopada). Pozyskano z https://pl.wikipedia.org/wiki/ Multipleks_kinowy

Sokołowski, D. (2005). Centralność a węzłowość większych miast w Polsce. Przegląd Geograficzny, 77(4), 507-526.

Sołtys, J. (2013). Usługi publiczne jako czynnik miastotwórczy i wyznacznik rangi miasta w sieci osadniczej na przykładzie małych miast Polski Północnej. Acta Universitatis Lodziensis Folia Geographica Socio-oeconomica, 15, 3-19.

Sołtys, J. (2016). Sub-regional service centres in reality and regional planning in Poland. Prace Naukowe Uniwersytetu Ekonomicznego we Wrocławiu, 431, 9-17.

Sołtys, J. (2017). Settlement Networks in Polish Spatial Development Regional Plans. IOP Conf. Series: Materials Science and Engineering, 245, 042083.

Suchta, J., Drońska, A., Celmer, A. (2007). Rola dużych i średnich miast województwa warmińsko-mazurskiego w procesie rozwoju regionu. Acta Scientiarum Polonorum, 5-20.

Śleszyński, P. (2013). Delimitacja miejskich obszarów funkcjonalnych stolic województw. Przegląd Geograficzny, 85(2), 173-197.

Środa-Murawska, S., Szymańska, D. (2014). Przemysły kultury w rozwoju miast - wybrane aspekty. Ekonomiczne Problemy Usług, 6, 85-98.

Wilk, W. (2003). Między zakupami a rozrywką - nowe znaczenie centrum handlowego. Prace i Studia Geograficzne, 32, 205-224.

Wyszukiwarka teatrów lub instytucji (2017, 10 listopada). Pozyskano z http://www.e-teatr.pl/ $\mathrm{pl} /$ instytucje/lista.html

Zaborowski, Ł. (2014). Sieć ośrodków regionalnych w Koncepcji przestrzennego zagospodarowania kraju 2030. Próba uporządkowania według wielkości i odległości. Przegląd Geograficzny, 86(4), 591-619. Pozyskano z http://rcin.org.pl/Content/51263/WA51_70658_r2014-t86-z4_Przeg-Geogr-Zaborows.pdf 
Jacek Sołtys, dr hab. inż. arch., Politechnika Gdańska, Wydział Architektury, Katedra Urbanistyki i Planowania Regionalnego. Absolwent Wydziału Architektury Politechniki Gdańskiej. Obecnie profesor Politechniki Gdańskiej. Prowadzone zajęcia dydaktyczne: planowanie regionalne (w latach 1975-2014), miejscowe planowanie przestrzenne, planowanie strategiczne, modele w gospodarce przestrzennej, projektowanie zagospodarowania rekreacyjnego i turystycznego. Zainteresowania naukowe: metody planowania (przestrzennego i strategicznego, w tym metoda scenariuszy), rozwój zrównoważony, typologia miast i regionów, sieć osadnicza, aktywizacja gospodarcza obszarów peryferyjnych. Pracował w wielu krajowych i międzynarodowych projektach badawczych. Autor dwóch książek i ponad 50 innych publikacji. Współautor ponad 30 strategii dla gmin. Członek Europejskiego Stowarzyszenia Nauk Regionalnych (ERSA) i Towarzystwa Urbanistów Polskich. Przewodnik turystyczny.

Jacek Sołtys, Gdansk University of Technology, Faculty of Architecture, Department of Urban Design and Regional Planning. Has graduated from Gdansk University of Technology, Faculty of Architecture. Currently, he is a professor of Gdansk University of Technology. Teaching Duties (courses taught) include: regional planning (covering the period of 1975-2014), local planning, strategic planning, models in spatial economy, designing of tourist and recreational areas development. Research interests: methods of planning (spatial, strategic, including scenario method), sustainable development, typology of towns and regions, settlement network, regional development of non-metropolitan areas. He has partaken in numerous international and national research projects. Author of two books and more than 40 other publications. Co-author of more than 30 strategies for municipalities. Member of European Regional Science Association and Society of Polish Town Planners. Tour guide.

\title{
Adres/address:
}

\author{
Politechnika Gdańska \\ Wydział Architektury \\ Katedra Urbanistyki i Planowania Regionalnego \\ ul. Gabriela Narutowicza 11/12, 80-233 Gdańsk, Polska \\ e-mail: jsoltys@pg.gda.pl
}

Sławomir Dorocki, dr, Uniwersytet Pedagogiczny w Krakowie, Instytut Geografii, Zakład Przedsiębiorczości i Gospodarki Przestrzennej, Polska. Absolwent studiów z zakresu geografii społeczno-ekonomicznej Uniwersytetu Pedagogicznego w Krakowie, doktor nauk humanistycznych w dyscyplinie historia (Instytut Europeistyki, Uniwersytet Jagielloński). Adiunkt w Instytucie Geografii Uniwersytetu Pedagogicznego w Krakowie. Zainteresowania badawcze skupiają się wokół problematyki regionów i procesów regionalizacji społeczno-gospodarczej, ze szczególnym uwzględnieniem zróżnicowania przestrzeni europejskiej, procesów integracji europejskiej i uwarunkowań historycznych, z zastosowaniem metod komputerowych i statystycznych w badaniach nad zróżnicowaniem przestrzeni.

Sławomir Dorocki, Ph.D., epartment of Entrepreneurship and Spatial Management, Institute of Geography, Pedagogical University of Cracow, Poland. He has graduated from the Pedagogical University of Cracow, MA degree in Geography, PhD in History (Institute of European Studies of the Jagiellonian University). Associate professor at the Pedagogical University of Cracow, Institute of Geography. His research interests are connected to regional problems and processes of socio-economic regionalisation, with particular emphasis on the diversity of Europe, processes of European integration, historical conditions, and application of computer and statistical methods in the study of diversity of space.

\section{Adres/address:}

Uniwersytet Pedagogiczny w Krakowie

Instytut Geografii

Zakład Przedsiębiorczości i Gospodarki Przestrzennej

ul. Podchorążych 2, 30-084 Kraków, Polska

e-mail: sdorocki@up.krakow.pl 